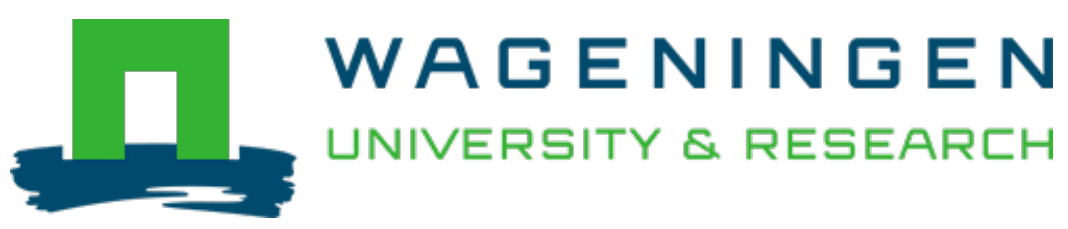

\title{
Faster recovery of soil biodiversity in native species mixture than in Eucalyptus monoculture after 60 years afforestation in tropical degraded coastal terraces
}

\author{
Global Change Biology \\ Wu, Wenjia; Kuang, Luhui; Li, Yue; He, Lingfeng; Mou, Zhijian et al \\ https://doi.org/10.1111/gcb.15774
}

This article is made publicly available in the institutional repository of Wageningen University and Research, under the terms of article $25 \mathrm{fa}$ of the Dutch Copyright Act, also known as the Amendment Taverne. This has been done with explicit consent by the author.

Article 25 fa states that the author of a short scientific work funded either wholly or partially by Dutch public funds is entitled to make that work publicly available for no consideration following a reasonable period of time after the work was first published, provided that clear reference is made to the source of the first publication of the work.

This publication is distributed under The Association of Universities in the Netherlands (VSNU) 'Article $25 \mathrm{fa}$ implementation' project. In this project research outputs of researchers employed by Dutch Universities that comply with the legal requirements of Article $25 \mathrm{fa}$ of the Dutch Copyright Act are distributed online and free of cost or other barriers in institutional repositories. Research outputs are distributed six months after their first online publication in the original published version and with proper attribution to the source of the original publication.

You are permitted to download and use the publication for personal purposes. All rights remain with the author(s) and / or copyright owner(s) of this work. Any use of the publication or parts of it other than authorised under article $25 \mathrm{fa}$ of the Dutch Copyright act is prohibited. Wageningen University \& Research and the author(s) of this publication shall not be held responsible or liable for any damages resulting from your (re)use of this publication.

For questions regarding the public availability of this article please contact openscience.library@,wur.nl 


\title{
Faster recovery of soil biodiversity in native species mixture than in Eucalyptus monoculture after 60 years afforestation in tropical degraded coastal terraces
}

\author{
Wenjia Wu' ${ }^{1,2,3,4}$ | Luhui Kuang, ${ }^{1,5}$ Yue Li, ${ }^{1,3}$ Lingfeng He ${ }^{1,5}$ | Zhijian Mou ${ }^{1,5}$ | \\ Faming Wang ${ }^{1,2,3}$ (1) | Jing Zhang ${ }^{1,3}$ | Jun Wang ${ }^{1,3} \mid$ Zhi'an Li $^{1,3}$ | Hans Lambers ${ }^{6}$ |

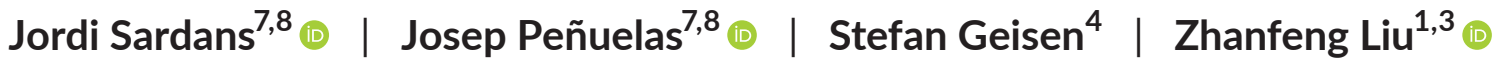 \\ ${ }^{1}$ Key Laboratory of Vegetation Restoration and Management of Degraded Ecosystems \& CAS Engineering Laboratory for Vegetation Ecosystem Restoration on
Islands and Coastal Zones, South China Botanical Garden, Chinese Academy of Sciences, Guangzhou, China
${ }^{2}$ Centre for Plant Ecology, Core Botanical Garden, Chinese Academy of Sciences, Guangzhou, China
${ }^{3}$ Southern Marine Science and Engineering Guangdong Laboratory (Guangzhou), Guangzhou, China
${ }^{4}$ Laboratory of Nematology, Wageningen University and Research, Wageningen, the Netherlands
${ }^{5}$ College of Resources and Environment, University of Chinese Academy of Sciences, Beijing, China
${ }^{6}$ School of Biological Sciences, University of Western Australia, Perth, WA, Australia
${ }^{7}$ CSIC, Global Ecology Unit CREAF-CSIC-UAB, Bellaterra, Catalonia, Spain
${ }^{8}$ CREAF, Cerdanyola del Valles, Catalonia, Spain
}

Correspondence

Zhanfeng Liu, Key Laboratory of Vegetation Restoration and Management of Degraded Ecosystems, South China Botanical Garden, Chinese Academy of Sciences, Guangzhou 510650, China. Email: liuzf@scbg.ac.cn

Stefan Geisen, Laboratory of Nematology, Wageningen University and Research, Droevendaalsesteeg 1, 6708 PB Wageningen, the Netherlands.

Email: stefan.geisen@wur.nl

Funding information

National Natural Science Foundation of China, Grant/Award Number: 41771278 , U1701246 and 31870463; Key Special Project for Introduced Talents Team of Southern Marine Science and Engineering Guangdong Laboratory, Grant/Award Number: GML2019ZD0408; Youth Innovation Promotion Association of Chinese Academy of Sciences; CAS Scholarship; Spanish Government project, Grant/Award Number: PID2019110521GB-I00; Catalan Government project, Grant/Award Number: SGR2017-1005; European Research Council, Grant/Award Number: SyG2013-610028 IMBALANCE-P

\section{Abstract}

Afforestation is an effective method to restore degraded land. Afforestation methods vary in their effects on ecosystem multifunctionality, but their effects on soil biodiversity have been largely overlooked. Here, we mapped the biodiversity and functioning of multiple soil organism groups resulting from diverse afforestation methods in tropical coastal terraces. Sixty years after afforestation from bare land (BL), plant species richness and the abundance of plant litter $\left(398 \pm 85 \mathrm{~g} \mathrm{~m}^{-2}\right)$ and plant biomass $\left(179 \pm 3.7 \mathrm{t} \mathrm{ha}^{-1}\right)$ in native tree species mixtures (MF) were restored to the level of native forests (NF; $287 \pm 21 \mathrm{~g} \mathrm{~m}^{-2}$ and $243.0 \pm 33 \mathrm{t} \mathrm{ha}^{-1}$, respectively), while Eucalyptus monoculture (EP) only successfully restored the litter mass $\left(388 \pm 43 \mathrm{~g} \mathrm{~m}^{-2}\right)$ to the level of NF. Soil fertility in EP and MF was increased but remained lower than in NF. For example, soil nitrogen and phosphorus concentrations in $\mathrm{MF}\left(1.2 \pm 0.2 \mathrm{~g} \mathrm{~kg}^{-1}\right.$ and $408 \pm 49 \mathrm{mg} \mathrm{kg}^{-1}$, respectively; $\left.p<0.05\right)$ were lower than in NF $\left(1.8 \pm 0.2 \mathrm{~g} \mathrm{~kg}^{-1}\right.$ and $523 \pm 24 \mathrm{mg} \mathrm{kg}^{-1}$, respectively; $p<0.05$ ). Soil biodiversity, abundance (except for nematodes), and community composition in MF were similar or greater than those in NF. In contrast, restoration with EP only enhanced the diversity of microbes and mites to the level of NF, but not for other soil biota. Together, afforestation with native species mixtures can end up restoring vegetation and most aspects of the taxonomic and functional biodiversity in soil whereas monoculture using fast-growing non-native species cannot. Native species mixtures show a greater potential to reach completely 
similar levels of soil biodiversity in local natural forests if they are received some more decades of afforestation. Multifunctionality of soil biotic community should be considered to accelerate such processes in future restoration practices.

KEYWORDS

afforestation, degraded land, native tree species mixtures, soil biodiversity, soil biota functioning, tropical coastal terraces

\section{1 | INTRODUCTION}

The importance of forests in the global carbon cycle that sustains life on Earth is undisputable (Malhi, 2012; Moomaw et al., 2020; Pugh et al., 2019; Stephens et al., 2007). The multifunctional roles of forests extend to many aspects such as moderating air temperature and supporting a vast array of biodiversity on Earth (Banerjee et al., 2020; IPCC, 2007; Makarieva \& Gorshkov, 2007). Forests also provide economic (e.g., timber, food, and fiber) and social benefits (e.g., subsistence for local populations and cultures; Gren \& AmuakwaMensah, 2020; Montagnini \& Jordan, 2005). Among numerous forests, tropical forests sequester 0.4 Pg C year ${ }^{-1}$ (Baccini et al., 2017) and contain over half of the world's terrestrial biodiversity (Myers, 1979). However, global climate change and human activities such as farming, mining, infrastructure expansion, are causing deforestation and subsequent degradation of soil properties and functions (Durán et al., 2015; Lowman et al., 2013; Veldkamp et al., 2020; van der Werf et al., 2009). So far, more than half of the tropical forests have been destroyed (Poorter et al., 2016), with the rest being under threat (Esquivel-Muelbert et al., 2019; Taubert et al., 2018). Over decades, afforestation has been used as one of the main methods to restore degraded ecosystems. Afforestation has major positive direct or indirect effects on soil fertility and above- and belowground communities (Lagnière et al., 2010; Liu et al., 2017; Ren et al., 2016; Wang et al., 2013, 2017, 2019).

Aboveground community and land-use changes such as deforestation and afforestation can directly or indirectly impact belowground communities (Bezemer et al., 2010; Biederman et al., 2008; Farska et al., 2014; George et al., 2019; Szoboszlay et al., 2017). For example, communities of microorganisms, as the most abundant and diverse organisms on the planet, change dramatically after deforestation (Crowther et al., 2014); natural restoration progress also showed that soil biodiversity becomes more connected and the soil takes up more carbon (Morriën et al., 2017); afforestation with greater tree species richness can enhance soil heterogeneity and thus contribute to soil biodiversity (Dickie et al., 2002; Liu et al., 2018; Strukelj et al., 2021). Such effects on soil biota can subsequently affect ecosystem functioning as soil biodiversity is required for ecosystem multifunctionality and is considered important for ecosystem restoration (Bardgett \& van der Putten, 2014; Guerra et al., 2021; Handa et al., 2014; Lefcheck et al., 2015; Soliveres et al., 2016). Soil biodiversity including connections in the soil food web declines in degraded ecosystems, leading to reduced functioning, with far-reaching consequences for restoration efforts (Ekelund et al., 2009; Harris, 2009; Kardol \& Wardle, 2010; Sánchez-Moreno \& Ferris, 2007). Increasing evidence suggests that several parameters of soil biodiversity decline including species richness and functional diversity which results in loss of soil functions (Heemsbergen et al., 2004; Nielsen et al., 2011; Saleem et al., 2019; Wagg et al., 2014). The abundance of soil biota, especially those at higher trophic levels, is considered essential for the stability of the ecosystem (Allesina \& Tang, 2012). Previous studies showed that afforestation positively affects the recovery of the biomass and diversity of soil biota (Gunina et al., 2017; Zhu et al., 2019). The B:F ratio, the abundance of arbuscular mycorrhizal fungi, the relative abundance of eukaryotic plant pathogens and plant parasite nematodes, and bacterivorous to fungivorous nematodes can indicate the functional characteristics of soil biota (Liu et al., 2019). However, afforestation effects on soil biodiversity and its functioning, especially integrated insights on multiple soil biodiversity groups at different trophic levels including abundance, diversity, community composition, and functional characteristics are largely unknown.

To investigate the afforestation effects on the recovery of belowground communities and their functioning, we studied the linkages between different afforestation practices and soil biodiversity in a tropical coastal forest in South China. The afforestation practices were initiated in the 1960 s with no afforestation practices (bare land) and Eucalyptus exserta rotation monoculture. Later, in 1974, some Eucalyptus forests were clear-cut and reforested with native tree species. We tested whether afforestation with native tree mixtures would restore the community composition, diversity, and abundance of diverse soil biota (bacteria, fungi, actinomycetes, arbuscular mycorrhizal fungi, protists, nematodes, and mites) to levels of undisturbed native forests, while we expected these effects to be less in Eucalyptus rotation monoculture forests (Hypothesis 1). Furthermore, we tested if afforestation with native tree mixtures would increase functional characteristics of soil biota more than afforestation with Eucalyptus rotation monocultures (Hypothesis 2).

\section{2 | MATERIALS AND METHODS}

\subsection{Site description}

The restoration study was initiated at the Xiaoliang Tropical Coastal Ecosystem Research Station, Chinese Academy of Sciences, in 1959. The site is located in Maoming City, Guangdong Province, 
China $\left(21^{\circ} 27^{\prime} \mathrm{N} ; 110^{\circ} 54^{\prime} \mathrm{E}\right)$, a region influenced by tropical monsoons. The mean annual temperature is $23^{\circ} \mathrm{C}$, the mean annual precipitation $1400-1700 \mathrm{~mm}$, and the soil is laterite developed from granite (Yao et al., 1984). Until the 1850s, this area was covered by evergreen broad-leaved seasonal rainforest. By the 1950s, about 40,000 ha of tropical monsoon forests were cut (Ren et al., 2007), and the bare land was covered by coarse sand and mineral aggregates rich in iron oxides and manganese ( $\mathrm{Yu} \& \mathrm{Pi}, 1985)$. Only a small patch of native forests was preserved. Native forests herein refer to tropical secondary forests, which were preserved for over 200 years. Recent vegetation surveys showed that the native forests were dominated by Cinnamomum camphora, Sterculia lanceolata, Cryptocarya chinensis, Syzygium levinei, Syzygium hancei, Schefflera octophylla, Auquilaria sinensis and exhibited a similar community composition as local climax vegetation (Cao \& Yu, 1998). Therefore, the native forests in our study represent the natural forests in the region.

In 1959, a long-term restoration experiment was started by establishing one reference area (3.7 ha) of bare land (BL), and two sites with restoration treatments (3.9 and 3.8 ha, respectively) in three geographically similar catchments (Figure 1; Ren et al., 2007), which have a similar slope $\left(<6^{\circ}\right)$ and initial soil properties ( $\mathrm{Li}$ et al., 1996). The initial soil organic matter concentration is $6 \mathrm{mg} \mathrm{g}^{-1}$ and total nitrogen concentration is $0.27 \mathrm{mg} \mathrm{g}^{-1}$ (Ren et al., 2007). Both restored catchments were initially restored with Eucalyptus exserta seedlings in the early 1960 s. In 1974 , one catchment was clear-cut and reforested with several species of native trees to become a mixed forest (MF), which now still has an average of 14.6 native tree species in $20 \times 20 \mathrm{~m}$ sample plots. The dominant tree species in MF are Aphanamixis polystachya, Schefflera octophylla, Carallia brachiate, Symplocos chunii, Acacia auriculaeformis, Photinia benthamiana, and Cinnamomum burmanni according to a survey performed in 2015. The other catchment remained as a Eucalyptus rotation monoculture (EP) that is harvested every 5 to 8 years. Finally, BL, MF, EP, and preserved native forests (NF) were used as four study sites. Five replicated plots $(20 \times 20 \mathrm{~m})$ at each site were designated for soil sampling during the wet season (June 2018). The native forest site is located about $2 \mathrm{~km}$ northeast of $\mathrm{BL}$, EP, and MF, and shares the same climate, soil type, and topographic conditions. The plots at each study site were at least $100 \mathrm{~m}$ apart and located at an equal distance from the high tidal mark at each site. All plots were inundated and exposed to the same tide effects.

\section{2 | Sample collections and analysis}

Diversity and biomass of plant community were measured during the survey in 2015 according to Wen et al. (1999). Plant litter was collected by three $30 \mathrm{~cm} \times 30 \mathrm{~cm}$ trappers, which were randomly distributed in each plot and then the collected litter was mixed into one composite sample. Litter samples were dried to constant weight at $60^{\circ} \mathrm{C}$ and weighted. Five random soil cores were collected in each plot by using a corer ( $5 \mathrm{~cm}$ in diameter, $20 \mathrm{~cm}$ in depth) and mixed to obtain one soil sample for each plot. Total organic carbon (TOC) and total nitrogen (TN) concentrations were analyzed by an elemental analyzer (Vario EL III, Elementar). Total soil phosphorus (TP) concentration was measured following $\mathrm{H}_{2} \mathrm{SO}_{4}-\mathrm{HClO}_{4}$ digestion and using the molybdenum antimony colorimetric method ( $\mathrm{Lu}, 2000)$. Soil $\mathrm{P}$ fraction extracting procedures were based on Hou et al. (2014). Dissolved organic carbon (DOC) was extracted by $0.5 \mathrm{M} \mathrm{K}_{2} \mathrm{SO}_{4}$ and measured by a TOC analyzer (TOC-VCSH, Shimadzu). $\mathrm{NH}_{4}{ }^{+} \mathrm{N}$ and $\mathrm{NO}_{3}{ }^{-} \mathrm{N}$ were measured by a flow injection analyzer (AA3, Bran Luebbe). Soil $\mathrm{pH}$ was measured with a $\mathrm{pH}$ meter in a 1:2.5 (w/v) suspension. The activities ( $\mu \mathrm{mol} \mathrm{g} \mathrm{g}^{-1}$ dry soil $\mathrm{h}^{-1}$ ) of $\beta$-1,4-glucosidase (BG), $\beta$-N-acetyl-glucosaminidase (NAG) and acid phosphatase (AP) were measured following Paz-Ferreiro et al. (2012) and the specific substrates were $p$-nitrophenyl- $\beta$-D-glucopyranoside, $p$-nitrophenyl$\mathrm{N}$-acetyl- $\beta$-D-glucosaminide and $p$-nitrophenyl-phosphate, respectively (Sigma).

\section{3 | Phospholipid fatty acids analysis}

Soil microbial communities were characterized by the phospholipid fatty acid (PLFA) method according to Bligh and Dyer (1959). An internal standard of 19:0 methyl ester was added to the extract before derivatization of PLFAs. Fatty acids were analyzed using a gas chromatograph (6890N, Agilent Technologies) with MIDI peak identification software (MIDI, Inc.). A number of fatty acids, i15:0, a15:0, i16:0, i17:0, and a17:0, were used as biomarkers for Gram-positive bacteria (GP);
FIGURE 1 Degraded coastal land and vegetation restoration in the study area

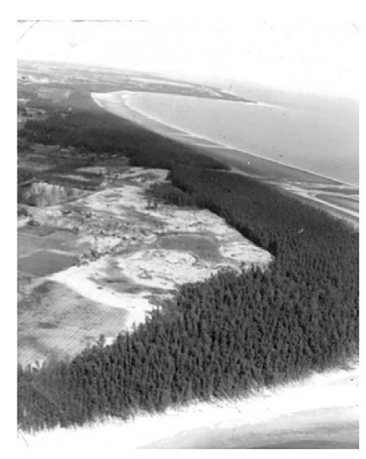

Coastal forests

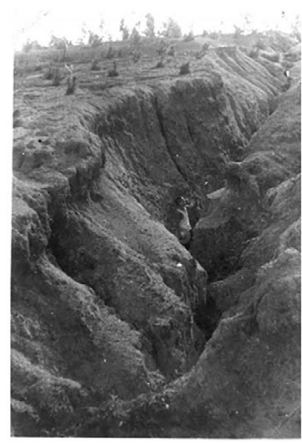

Degraded coastal land

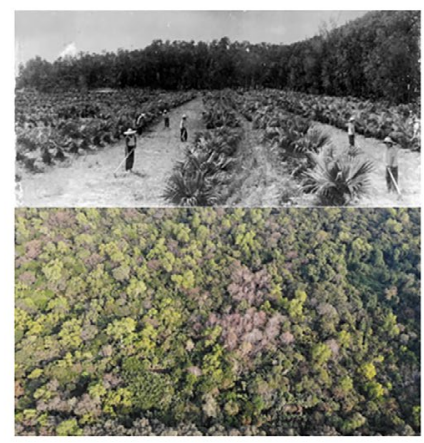

Vegetation restoration 


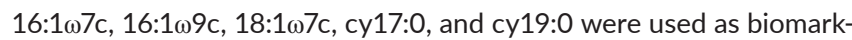
ers for Gram-negative bacteria (GN). Saprophytic fungal biomarkers

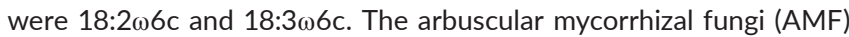
biomarker was $16: 1 \omega 5 c$, and actinomycete biomarkers were 10Me16:0, 10Me17:0, and 10Me18:0. The total microbial PLFA concentration was also calculated. All PLFA concentrations were expressed as nmol g ${ }^{-1}$ dry soil. "Microbe" in our study specifically refers to the soil microbial communities, which include fungi, bacteria, AMF, and actinomycetes.

\section{4 | DNA extraction and high-throughput sequencing of nematodes and protists}

Soil samples for high-throughput sequencing were stored at $-80^{\circ} \mathrm{C}$ before processing. Total soil DNA was extracted from $0.25 \mathrm{~g}$ soil using the PowerSoil DNA kit (MOBIO). The isolated DNA was stored at $-80^{\circ} \mathrm{C}$ until the PCR stage. Illumina Hiseq sequencing was used to assess the protist and nematode communities through massively parallel sequencing of $18 \mathrm{~S}$ rDNA gene. The $18 \mathrm{~S}$ rDNA gene of protists was amplified with the primer pair 1380F ( $3^{\prime}$-CCCTGCCHTTTGTACACAC-5') and 1510R ( $3^{\prime}$-CCTTCYGCAGGTTCACCTAC-5'; Amaral-Zettler et al., 2009). The primer pair used to amplify nematodes was NF1 (3'-GGTGGTGCATGGCCGTTCTTAGTT-5') and 18Sr2b (3'-TACAAAGGGCAGGGACGTAAT-5'; Porazinska et al., 2009). PCR amplification and sequencing were made by MAGIGENE. The OTUs of protists were grouped into four feeding groups: phagotrophs, plant pathogens, parasites, and phototrophs (Xiong et al., 2018), and those of nematodes were grouped into four feeding groups: bacterivores (BF), fungivores (FF), plant parasites (PP), and omnivores/predators (OP; Yeates et al., 1993).

\subsection{Extraction and taxonomic identifications of mites and nematodes}

To obtain abundance and feeding group composition data of nematodes, morphological method was used also. Molecular information on mesofauna is in its infancy, and therefore we only performed standardized morphological information. Mites were extracted from the soi and litter samples and visually identified at the genus level using an inverted microscope (Nikon) at South China Agricultural University. Individual numbers of fungivorous and omnivorous/predatory mites (Laliberté et al., 2017) were counted, respectively. Nematodes were extracted from $100 \mathrm{~g}$ fresh soil by Baermann funnel (Whitehead \& Hemming, 1965). The first 100 nematodes were identified using a reversed light microscope (Nikon) and individual numbers of four feeding groups (Yeates et al., 1993) were counted. If there were less than 100 nematodes, then all nematodes were identified and counted. Individual numbers of mites and nematodes per $100 \mathrm{~g}$ dry soil were calculated based on the soil moisture data. Nematode channel ratio (NCR) was calculated as $\mathrm{BF} /(\mathrm{BF}+\mathrm{FF})$, where $\mathrm{BF}$ and $\mathrm{FF}$ are the relative abundance of bacterial-feeding and fungal-feeding nematodes, respectively (Yeates, 2003).

\subsection{Bioinformatics and statistical analyses}

The sequences were demultiplexed and trimmed with a read quality score above 30 using FastQC (Andrews, 2012). Sequences with lengths less than $150 \mathrm{bp}$ and rare sequences were removed. Putative chimeric sequences were detected and removed using Mothur (Schloss et al., 2009). High-quality sequences were assigned to OTUs at $\geq 97 \%$ similarity level. Nematode and protist OTUs were taxonomically assigned at the genus level by blasting against SILVA v.132 (https://www.arbsilva.de) using the classify command in Mothur. Streptophyta, Fungi, Metazoa, and ambiguous taxa in eukaryotes were removed from the OTU table. Diversity indices at the OTU level were calculated.

Alpha diversity of microbial groups was calculated based on the data of PLFA biomarkers (de Vries et al., 2012), and the diversity of various soil faunal groups was calculated based on OTU or morphology data. Statistical analyses were done in SPSS v.23 (SPSS). One-way ANOVAs were used to analyze differences in soil properties, PLFA concentrations, diversity, abundance of soil biota among sample sites with statistical differences considered significant at $p<0.05$. The least-significant difference (LSD) test was used to assess treatment differences in one-way ANOVA analyses. Graphs were created using GraphPad Prism 7 (GraphPad Software). The PCoA analysis of soil microbial and animal communities based on OTUs or genera data was performed using R (version 3.6.1, R Development Core Team, 2016) with the "vegan", "ggplot2", and "plyr" package.

The PLFA data of soil bacteria, fungi, actinomycetes, and AMF, the abundance data of soil nematodes and mites at the genus level, and the OTU numbers of the 50 most-abundant protists (Table S6) were used for the co-occurrence network analysis using $R$ version 3.6.1 ( $R$ Development Core Team, 2016). The visualization of the correlation matrix was created, and network properties were inferred by Gephi version 0.9.2 (https://gephi.org). Significant correlations $(p<0.05)$ including both positive and negative correlations with values greater than 0.9 were visualized.

Structural equation models (SEMs) were constructed by AMOS (SPSS) to analyze the effects of plant resource input by afforestation on soil fertility, the diversity, and abundance of soil biota, and further on soil biodiversity functioning. We defined soil biodiversity functioning by the combination of the B:F ratio, the abundance of AMF, BF:FF nematode ratio, the relative abundance of plant pathogenic protists and PP nematodes (Liu et al., 2019). Positive effects on these represent an increase of these variables which means a stronger bacterial energy channel and greater relative abundance of plant pathogens, while negative effects represent a decrease of these variables which means a stronger fungal energy channel and lower relative abundance of plant pathogens. Detailed information about the variables used for SEM analysis is listed in Table S1. Data of $\mathrm{BL}$ were not used for SEM as they cannot be compared with forests. Outliers found in litter biomass data (one in EP and one in MF) were winsorized (90\%) as they would cause spurious correlations. Maximum likelihood estimation was used to fit the covariance matrix to the model. Chi-square value, associated $p$-value $(p>0.05)$, goodness-of-fit-index (GFI > 0.90), and root mean square error of 
approximation (RMSEA < 0.05) were measured to ensure the model adequately fitted.

\section{3 | RESULTS}

\subsection{Afforestation effects on soil properties and aboveground community}

Soil fertility, as indicated by the concentrations of TOC, DOC, $\mathrm{TN}, \mathrm{TP}, \mathrm{NH}_{4}{ }^{+}-\mathrm{N}$, and $\mathrm{NO}_{3}{ }^{-}-\mathrm{N}$ was greatly enhanced by afforestation, but DOC, TP, TN, and $\mathrm{NO}_{3}{ }^{-} \mathrm{N}$ concentrations were still lower than those in NF $(p<0.05$; Figure 2; Table S2). TOC concentration in MF $\left(19 \pm 3.1 \mathrm{~g} \mathrm{~kg}^{-1}\right)$ was restored to the level of NF $\left(24 \pm 2.0 \mathrm{~g} \mathrm{~kg}^{-1}\right)$, but not in EP $\left(5.8 \pm 0.3 \mathrm{~g} \mathrm{~kg}^{-1}\right)$. DOC concentration in both EP $\left(137 \pm 6.0 \mathrm{~g} \mathrm{~kg}^{-1}\right)$ and MF $\left(271 \pm 18 \mathrm{~g} \mathrm{~kg}^{-1}\right)$ were increased but not to the level of NF $\left(552 \pm 13 \mathrm{~g} \mathrm{~kg}^{-1} ; p<0.05\right)$. TN and TP concentration in MF were both increased compared with $\mathrm{BL}$ and $\mathrm{EP}\left(1.2 \pm 0.2 \mathrm{~g} \mathrm{~kg}^{-1}\right.$ and $408 \pm 49 \mathrm{mg} \mathrm{kg}^{-1}$, respectively; $p<0.05)$, but were lower than in NF $\left(1.8 \pm 0.2 \mathrm{~g} \mathrm{~kg}^{-1}\right.$ and $523 \pm 24 \mathrm{mg} \mathrm{kg}^{-1}$, respectively; $\left.p<0.05\right)$. The $\mathrm{NO}_{3}{ }^{-}-\mathrm{N}$ concentration in both EP $\left(0.1 \pm 0.0 \mathrm{mg} \mathrm{kg}^{-1}\right)$ and MF $\left(2.5 \pm 1.0 \mathrm{mg} \mathrm{kg}^{-1}\right)$ was not yet restored to the level of NF $\left(8.1 \pm 0.9 \mathrm{mg} \mathrm{kg}^{-1} ; p<0.05\right)$, while the $\mathrm{NH}_{4}{ }^{+}-\mathrm{N}$ concentration in $\mathrm{EP}\left(1.2 \pm 0.1 \mathrm{mg} \mathrm{kg}^{-1}\right)$ was restored to the level of NF $\left(0.8 \pm 0.3 \mathrm{mg} \mathrm{kg}^{-1}\right)$ and it was even higher in MF $\left(1.8 \pm 0.3 \mathrm{mg} \mathrm{kg}^{-1} ; p<0.05\right)$. The soil $\mathrm{C}: \mathrm{N}$ ratio increased to the same level in EP $(15.8 \pm 0.4)$ and MF $(15.5 \pm 0.4)$ and was lower in NF (13.0 $\pm 0.2 ; p<0.05)$. Soluble $\mathrm{P}$ was low in EP compared with all other sample sites $\left(0.6 \pm 0.0 \mathrm{mg} \mathrm{kg}^{-1} ; p<0.05\right)$, while available $P$, residual $P$, and $B G$ did not show significant differences (Table S2) and the other variables referring to carbon, nitrogen, phosphorus, and enzyme activity were all increased by afforestation (Table S2). Soil moisture content $(M C)$ in MF $(30.2 \pm 0.8 \%)$ was significantly increased to the level of NF $(29.5 \pm 0.5 \%)$, and $\mathrm{pH}$ was significantly decreased in MF $(4.2 \pm 0.0)$ to the level of NF ( $4.1 \pm 0.1$; Figure 1 ; Table S2). Plant biomass (including above- and belowground biomass) in MF (179 $\left.\pm 3.7 \mathrm{t} \mathrm{ha}^{-1}\right)$ was significantly improved to the level of NF $\left(243 \pm 33.0 \mathrm{tha}^{-1}\right)$. Litter biomass in EP $\left(388 \pm 43 \mathrm{~g} \mathrm{~m}^{-2}\right)$ and MF $\left(398 \pm 85 \mathrm{~g} \mathrm{~m}^{-2}\right)$ was the same as in NF $\left(287 \pm 21 \mathrm{~g} \mathrm{~m}^{-2}\right)$. Tree species richness in MF $(14.6 \pm 0.9)$ was also similar as in NF (12.6 \pm 0.4; Figure 3).

\subsection{Afforestation effects on belowground communities}

Following afforestation, the microbial Shannon-Wiener Index in MF $(2.53 \pm 0.01)$ was higher than in $\mathrm{BL}(2.47 \pm 0.00)$ and even higher than in NF ( $2.49 \pm 0.00 ; p<0.05$; Figure 3$)$. The total microbial PLFA concentrations in MF $\left(22.4 \pm 3.1 \mathrm{nmol} \mathrm{g}^{-1}\right)$ were significantly increased to the level of NF $\left(36.2 \pm 2.9 \mathrm{nmol} \mathrm{g}^{-1}\right)$, but not in EP $\left(10.6 \pm 0.4 \mathrm{nmol} \mathrm{g}^{-1}\right.$; Figure 3). Neither the monoculture nor the mixture had significant effects on the diversity of protists and their relative abundance among all eukaryote reads (Figure 3). The abundance of nematodes (per $100 \mathrm{~g}$ dry soil) was increased by afforestation, but MF (20.6 \pm 3.7$)$ was not yet restored to the level of NF (60.0 \pm 15.0 ; Figure 3). The diversity of nematodes in EP $(0.6 \pm 0.3)$ was significantly lower than that in MF $(1.6 \pm 0.1)$ and NF $(1.7 \pm 0.4$; Figure 3$)$. Mite diversity increased in MF $(2.0 \pm 0.2)$ which was even higher than that in NF $(1.4 \pm 0.2 ; p<0.05)$, but its abundance showed no significant variation (Figure 3$)$. The activities of BG $(0.4 \pm 0.1 \mu \mathrm{mol}$ $\mathrm{g}^{-1}$ dry soil $\left.\mathrm{h}^{-1}\right)$, NAG $\left(0.2 \pm 0.0 \mu \mathrm{mol} \mathrm{g}^{-1}\right.$ dry soil $\left.\mathrm{h}^{-1}\right)$, and AP $\left(4.9 \pm 0.4 \mu \mathrm{mol} \mathrm{g}^{-1}\right.$ dry soil $\left.\mathrm{h}^{-1}\right)$ in MF were increased to the level of $\mathrm{NF}\left(0.6 \pm 0.1 \mu \mathrm{mol} \mathrm{g}^{-1}\right.$ dry soil $\mathrm{h}^{-1}, 0.2 \pm 0.0 \mu \mathrm{mol} \mathrm{g}^{-1}$ dry soil $^{-1}$ and $4.2 \pm 0.2 \mu \mathrm{mol} \mathrm{g}^{-1} \mathrm{dry}$ soil $\mathrm{h}^{-1}$, respectively; $p<0.05$ ) and the activity of AP in MF was higher than in EP ( $p<0.05$; Table S2). More detailed information of the changes of belowground communities is shown in Tables S3-S5. Detailed information of the high-throughput sequencing results and identifications of the belowground communities are shown in supplemental results (Supplemental file S1) and Table S7.

For the changes in feeding groups and community composition (Figures $3-5$ ), the relative abundance of fungi and actinomycetes in both EP $(11.7 \pm 0.8 \%$ and $15.6 \pm 0.6 \%$, respectively) and MF (17.1 $\pm 0.9 \%$ and $16.2 \pm 0.3 \%$, respectively) were restored to the level of NF (13.3 $\pm 1.3 \%$ and $15.3 \pm 0.2 \%$, respectively). The GP:GN ratio also significantly decreased after afforestation (Table
FIGURE 2 Main variation referring to soil properties on bare land (BL), Eucalyptus rotation monoculture (EP), native tree species mixture (MF), and native forest (NF). Data are means \pm SE $(n=5)$. Bars with different lowercase letters are significantly different $(p<0.05$, LSD). DOC, Dissolved organic carbon; MC, Soil moisture content; TN, Total nitrogen; TOC, Total organic carbon; TP, Total phosphorus
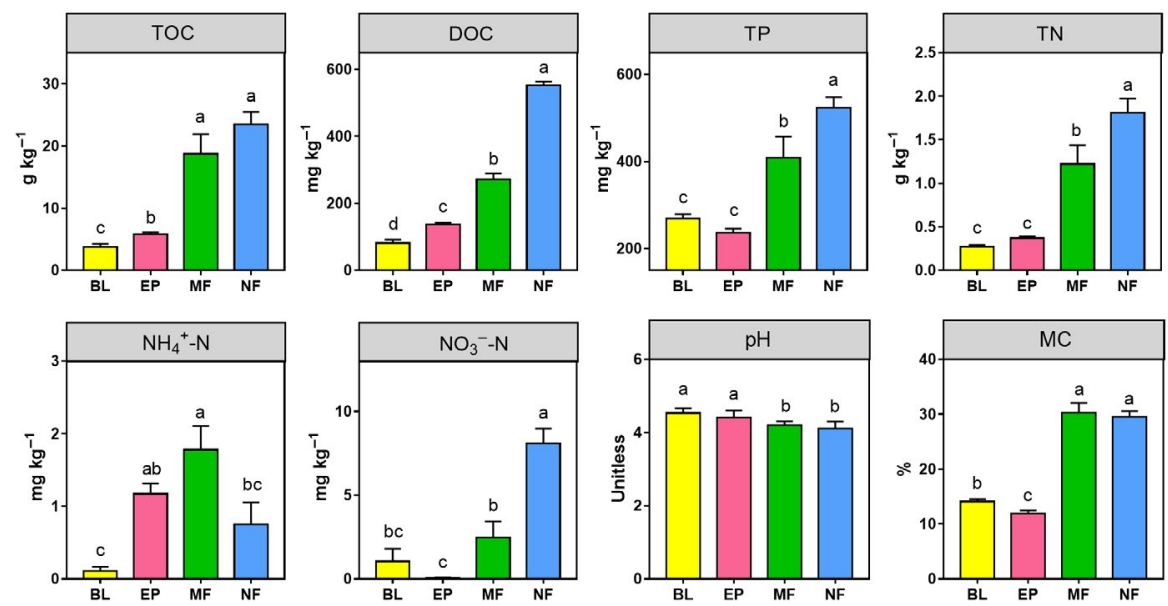
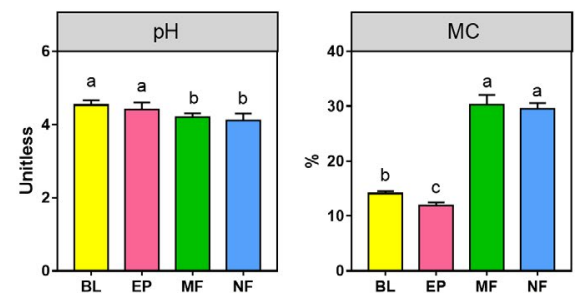

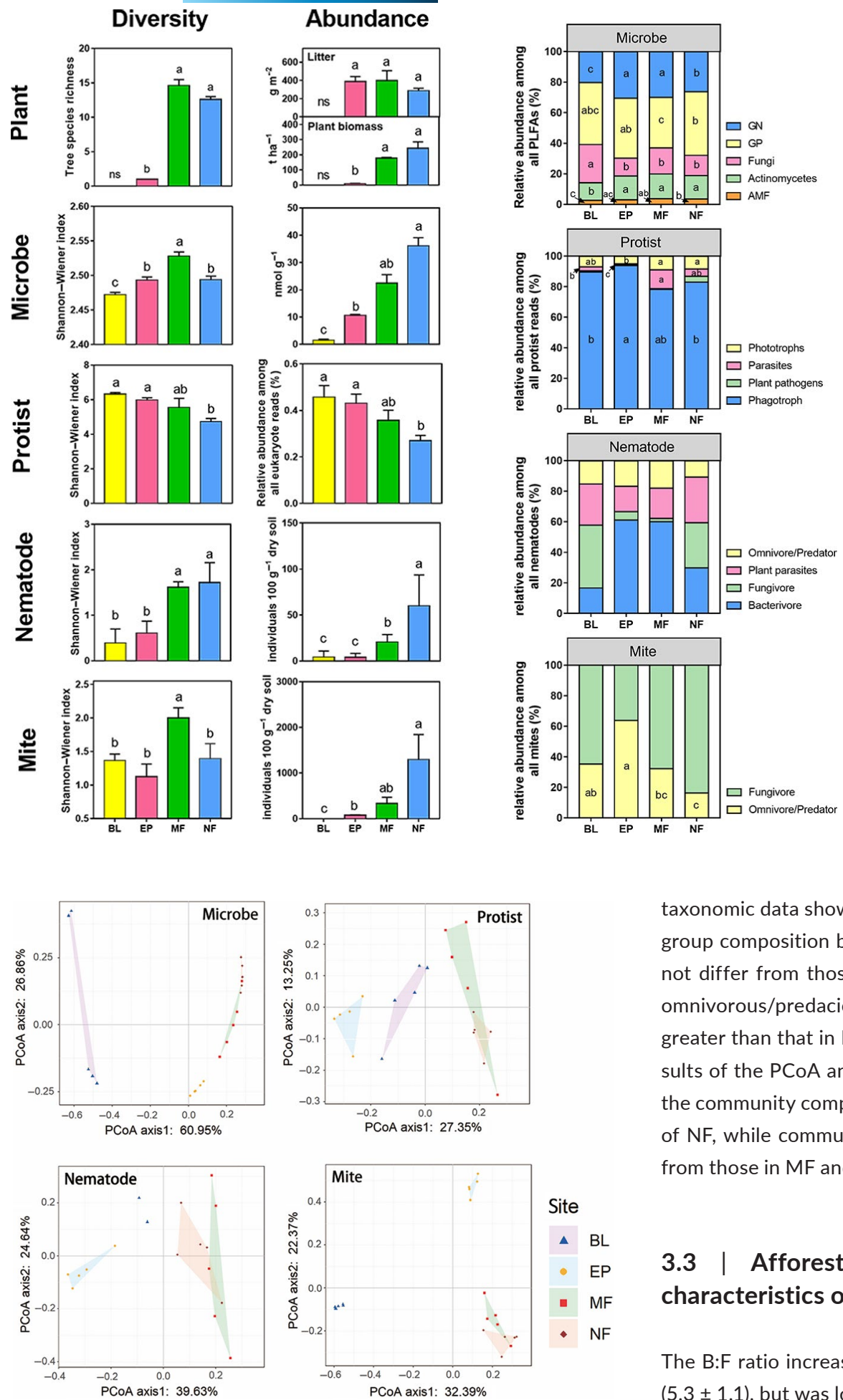

FIGURE 4 Results of PCoA analyses of different soil biota communities on bare land (BL), a Eucalyptus monoculture (EP), a native tree species mixture (MF), and a native forest (NF). "Microbe" specifically refers to the soil microbial communities, which include fungi, bacteria, AMF and actinomycetes

S3), and was lower in EP $(1.3 \pm 0.0)$ and MF $(1.1 \pm 0.0)$ than in NF $(1.6 \pm 0.0 ; p<0.05)$. The relative abundance of phagotrophic protists decreased from $89.7 \pm 0.7 \%$ in $\mathrm{BL}$ to $78.3 \pm 6.1 \%$ in MF. The
FIGURE 3 Diversity and abundance of soil biota and plant parameters, and relative abundance of different trophic groups on bare land (BL), a Eucalyptus monoculture (EP), a native tree species mixture (MF) and a native forest (NF).

Data are means $\pm \operatorname{SE}(n=5)$. Bars with different lowercase letters are significantly different $(p<0.05$, LSD), and only data with significant differences are marked with a lowercase letter. The word "Microbe" specifically refers to the soil microbial communities, which include fungi, bacteria, AMF, and actinomycetes. GN: Gram-negative bacteria; GP: Grampositive bacteria taxonomic data showed no significant changes in nematode feeding group composition by afforestation (Table S5). The NCR values did not differ from those in NF (Table S4). The relative abundance of omnivorous/predacious mites in EP (63.9 $\pm 12.7 \%)$ was significantly greater than that in MF $(32.3 \pm 8.5 \%)$ and NF $(16.3 \pm 4.3 \%)$. The results of the PCOA analysis based on OTU/genera data showed that the community composition of soil biota in MF overlapped with that of NF, while community compositions in $\mathrm{BL}$ and $\mathrm{EP}$ were different from those in MF and NF.

\section{3 | Afforestation effects on functional characteristics of soil biota}

The B:F ratio increased in EP $(6.1 \pm 1.0)$ to the same level as in NF $(5.3 \pm 1.1)$, but was lower in MF $(3.7 \pm 0.6 ; p<0.05)$. The abundance of AMF in both EP $\left(0.32 \pm 0.01 \mathrm{nmol} \mathrm{g}^{-1}\right)$ and MF $(0.84 \pm 0.16 \mathrm{nmol}$ $\left.\mathrm{g}^{-1} ; p<0.05\right)$ were increased, but it was still lower than that in NF $\left(1.30 \pm 0.10 \mathrm{nmol} \mathrm{g}{ }^{-1} ; p<0.05\right)$. The relative abundance of plant pathogenic protists and plant parasite nematodes did not differ from that in NF (Table S5). The BF:FF nematode ratio in MF (11 \pm 0.0$)$ increased and was higher than that in NF $(2.3 \pm 0.8)$.

The results of the co-occurrence network and SEM (Figures S1S3) should be taken with caution due to the low number of replicates, but we wanted to explore the entire soil food web characteristics through these results. However, no clear patterns of potentially 
FIGURE 5 Variables of functional characteristics of soil biota on bare land (BL), a Eucalyptus monoculture (EP), a native tree species mixture (MF), and a native forest (NF). Data are means \pm SE $(n=5)$. Bars with different lowercase letters are significantly different $(p<0.05$, LSD), and only data with significant differences are marked with a lowercase letter. BF, bacterivores; FF, fungivores; PP, plant parasites

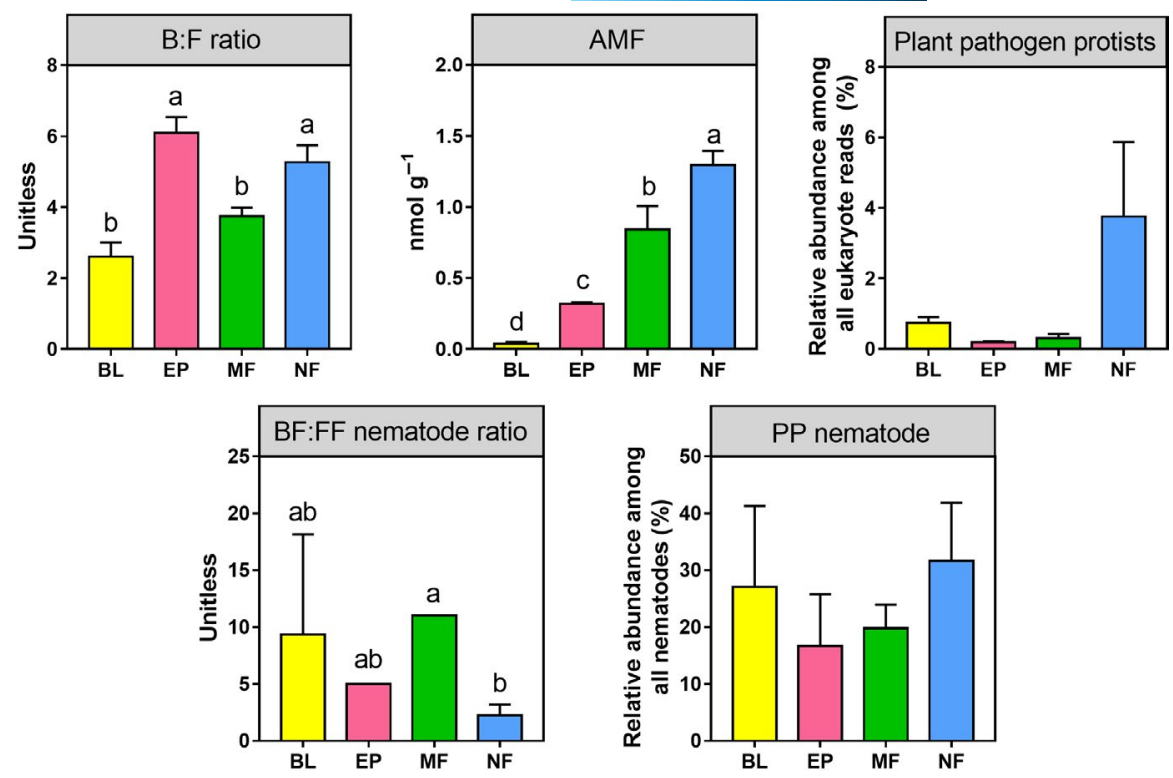

increased network complexity in mixed and natural forests were found and no significant effects among the diversity, abundance, and soil biodiversity functioning were found.

\section{DISCUSSION}

We provide partial support for our first hypothesis. MF, indeed, more successfully restored the belowground biodiversity than EP, but not always to the level of NF. For example, the abundance of nematodes and soil fertility in MF was higher than that in EP, but it was not yet restored to the level of NF. Community compositions of all soil biota in MF resembled that of NF, but fundamentally differed in EP and BL. Underlying drivers of these patterns could have been plant resource input and plant species richness as carbon pumps into soils, as these were greater in MF than in EP, and obviously in BL (Eissfeller et al., 2013; Schneider et al., 2012). Furthermore, plant species richness affects soil biota not only through litter input, but also through other resources such as root exudates (Eisenhauer et al., 2010; Preece \& Peñuelas, 2016; Srivastava et al., 2009). Mixtures of native tree species might restore soil biodiversity by providing more niches for soil biota, thereby increasing species richness. The resulting soil biodiversity might be more like that in native forests which might be adapted to the local soil biodiversity (Dassen et al., 2017; Dawud et al., 2017; Lang \& Polle, 2011; Leff et al., 2018; Orwin et al., 2006). The significantly decreased pH value and increased soil moisture in MF likely further influenced soil biodiversity, such as shown for bacteria, protists, and nematodes (Bates et al., 2013; Delgado-Baquerizo et al., 2018; Hu \& Qi, 2010; Rousk et al., 2010). This emphasizes the positive role of a diverse mixture of trees in restoration efforts to increase ecosystem multifunctionality (Di Sacco et al., 2021). The profound difference between MF and EP including reduced biodiversity in EP can also be explained by constant rotation every 5-8 years in EP that led to the temporary loss of input of plant resources which might further disturb soil biodiversity
(Pawson et al., 2013). A peculiar finding was the contrasting pattern observed for protists: unlike most other soil biota, protists showed a slightly decreased trend in both diversity and relative abundance among all eukaryotes following afforestation. This pattern might be caused by the nature of the data as sequence data are relative (Geisen et al., 2018; Geisen \& Bonkowski, 2018). We have shown a profound total increase of fungal biomass which might be greater than that of protists, meaning that protists might indeed increase in absolute terms. The exact meaning of the relative decrease of protists needs further examination. We assume that protists feed more on fast-growing bacteria and yeasts, and therefore increase hyphae-forming fungi (Geisen et al., 2016), which are representative for later-successional plant communities such as diverse and mature forests (Hannula et al., 2017). As such, the ratio of fungi to protists may be a meaningful and easy-to-apply measure to trace successful restoration.

We confirm our second hypothesis that afforestation with native tree mixtures increased functional characteristics of soil biota more than that of a Eucalyptus rotation monoculture. The lower B:F ratio in MF than in EP indicates a more fully restored status in MF, because the $B: F$ ratio decreases during secondary succession at a global level (Fierer et al., 2009; Zhou et al., 2017), and forest degradation consistently decreases the abundance of fungi (Zhou et al., 2018). It also suggests that the microbial community in MF was more stable and more resistant to a lower quality or availability of resources than those in EP. A possible explanation is that $\mathrm{NH}_{4}{ }^{+}-\mathrm{N}^{-}$and $\mathrm{NO}_{3}{ }^{-} \mathrm{N}$ concentrations in EP were lower than those in MF, although soil $\mathrm{C}: \mathrm{N}$ ratio did not differ in EP and MF. Fungi require less nitrogen for growth than bacteria (Bardgett \& McAlister, 1999; De Deyn et al., 2008) which makes them less dependent on high nitrogen availability in the soil (Fierer et al., 2009). Higher activities of the microbial enzymes in MF than in EP suggest a more active microbial community, which could promote the cycling of C, N, and P (Stott, 2019). The increased abundance of AMF in MF suggests more favorable functional characteristics because AMF are crucial for the deposition of slow-cycling 
organic compounds (Wilson et al., 2009), formation of soil aggregates that protect organic matter from decomposition (Rillig et al., 2002), phosphorus uptake, cycling of nitrogen, and protection of plants against rhizosphere pathogens (Feng et al., 2002; Govindarajulu et al., 2005). High soil biodiversity supposedly enhances the functioning of soil biota which might accelerate restoration (Bardgett $\&$ van der Putten, 2014; Kardol et al., 2006; Lefcheck et al., 2015; Liu et al., 2019; Soliveres et al., 2016). However, even though the diversity and biomass of aboveground community and the diversity of soil biota in MF was restored to the level of NF, soil fertility in MF was still lower than that in NF, whereas the abundance of soil biota showed a similar restoration trend as soil fertility. Among soil biodiversity, the abundance of higher trophic level organisms is of major importance for soil food web functions and soil health (Ferris \& Bongers, 2006; Ferris et al., 2004; Sánchez-Moreno \& Ferris, 2007) and is closely related to the increased abundance of microbes and plant resources (Bardgett \& Wardle, 2010; Scherber et al., 2010). Also, intense predator-prey interactions likely increase ecosystem stability (Allesina \& Tang, 2012). However, the abundance of nematodes and mites, which contain consumers and predators at higher trophic levels in MF were still lower than those in NF. This may lead to reduced predator-prey interactions and cause a further reduction of the transfer of energy, carbon, and nitrogen, etc., that released from aboveground community transferred into and sequestered by the soil food web (Bartley et al., 2019; Coleman, 2008; Zhang et al., 2021). Thus, insufficient soil fertility in restored sites may be explained by incomplete restoration outcomes of soil biodiversity. The results of the co-occurrence network and SEM should be interpreted with caution because of the low number of replicates, which may explain why no clear patterns of potentially increased network complexity in natural and mixed forests were found and no significant effects among diversity, abundance, and functioning of soil biota.

\section{5 | CONCLUSIONS}

Our study provides detailed results on afforestation effects on the restoration of belowground biodiversity and its functioning. We conclude that afforestation with native tree species mixtures restores soil biodiversity more effectively including its functioning. Although 60 years afforestation with native species did not reach the full level of soil fertility, abundance, and functional characteristics of belowground community of the more than 200-year-old native forest, certain traits of diversity of soil biota reached similar levels of the native forest. This indicates that the overall habitat restoration may take several decades, with likely consequences for ecosystem functioning. However, the afforestation with native species can end up reaching similar levels of diversity of native forests whereas plantations using fast-growing non-native species cannot.

\section{ACKNOWLEDGEMENTS}

This work was supported by the National Natural Science Foundation of China (Grant Nos. 41771278, U1701246 and 31870463), the Key
Special Project for Introduced Talents Team of Southern Marine Science and Engineering Guangdong Laboratory (Guangzhou; Grant No. GML2019ZD0408), Youth Innovation Promotion Association of Chinese Academy of Sciences, and CAS Scholarship. J.P. and J.S. would like to acknowledge the financial support from the Spanish Government project PID2019-110521GB-I00, the Catalan Government project SGR2017-1005, and the European Research Council Synergy project SyG-2013-610028 IMBALANCE-P. We would like to thank Fuchun Tong for assistance in mite taxonomic identification, and Weixin Zhang, Yuanhu Shao, and Xiaoke Zhang for their insightful comments.

\section{CONFLICT OF INTEREST}

The authors declare to have no conflict of interest.

\section{DATA AVAILABILITY STATEMENT}

All data that support the findings of this study are available in Zenodo (https://doi.org/10.5281/zenodo.4769247). The raw data and relative information of high-throughput sequencing are available in the US National Center for Biotechnology Information (NCBI; https://www.ncbi.nlm.nih.gov) under BioProject PRJNA730783.

\section{ORCID}

Faming Wang (iD) https://orcid.org/0000-0002-7543-6779 Jordi Sardans (D) https://orcid.org/0000-0003-2478-0219

Josep Peñuelas (D) https://orcid.org/0000-0002-7215-0150

Zhanfeng Liu (D) https://orcid.org/0000-0002-6602-6196

\section{REFERENCES}

Allesina, S., \& Tang, S. (2012). Stability criteria for complex ecosystems. Nature, 483, 205-208. https://doi.org/10.1038/nature10832

Amaral-Zettler, L. A., McCliment, E. A., Ducklow, H. W., \& Huse, S. M. (2009). A method for studying protistan diversity using massively parallel sequencing of $\mathrm{V} 9$ hypervariable regions of small-subunit ribosomal RNA genes. PLoS One, 4, e6372. https://doi.org/10.1371/ journal.pone.0006372

Andrews, S. (2012). FastQC-A quality control tool for high throughput sequence data. http://www.bioinformatics.babraham.ac.uk/proje cts/fastqc/

Baccini, A., Walker, W., Carvalho, L., Farina, M., Sulla-Menashe, D., \& Houghton, R. A. (2017). Tropical forests are a net carbon source based on aboveground measurements of gain and loss. Science, 358, 230-234. https://doi.org/10.1126/science.aam5962

Banerjee, A., Jhariya, M. K., Yadav, D. K., \& Raj, A. (2020). Environmental and sustainable development through forestry and other resources. CRC Press. https://doi.org/10.1201/9780429276026

Bardgett, R. D., \& McAlister, E. (1999). The measurement of soil fungal: Bacterial biomass ratios as an indicator of ecosystem self-regulation in temperate meadow grasslands. Biology and Fertility of Soils, 29, 282-290. https://doi.org/10.1007/s003740050554

Bardgett, R. D., \& van der Putten, W. H. (2014). Belowground biodiversity and ecosystem functioning. Nature, 515, 505-511. https://doi. org/10.1038/nature13855

Bardgett, R. D., \& Wardle, D. A. (2010). Aboveground-belowground linkages: Biotic interactions, ecosystem processes, and global change. Oxford University Press.

Bartley, T. J., McCann, K. S., Bieg, C., Cazelles, K., Granados, M., Guzzo, M. M., MacDougall, A. S., Tunney, T. D., \& McMeans, B. C. (2019). Food 
web rewiring in a changing world. Nature Ecology and Evolution, 3, 345-354. https://doi.org/10.1038/s41559-018-0772-3

Bates, S. T., Clemente, J. C., Flores, G. E., Walters, W. A., Parfrey, L. W., Knight, R., \& Fierer, N. (2013). Global biogeography of highly diverse protistan communities in soil. The ISME Journal, 7, 652-659. https://doi.org/10.1038/ismej.2012.147

Bezemer, T. M., Fountain, M. T., Barea, J. M., Christensen, S., Dekker, S. C., Duyts, H., van Hal, R., Harvey, J. A., Hedlund, K., Maraun, M., Mikola, J., Mladenov, A. G., Robin, C., de Ruiter, P. C., Scheu, S., Setälä, H., Šmilauer, P., \& van der Putten, W. H. (2010). Divergent composition but similar function of soil food webs of individual plants: Plant species and community effects. Ecology, 91, 30273036. https://doi.org/10.1890/09-2198.1

Biederman, L. A., Boutton, T. W., \& Whisenant, S. G. (2008). Nematode community development early in ecological restoration: The role of organic amendments. Soil Biology and Biochemistry, 40, 2366-2374. https://doi.org/10.1016/j.soilbio.2008.05.017

Bligh, E. G., \& Dyer, W. J. (1959). A rapid method of total lipids extraction and purification. Canadian Journal of Biochemistry and Physiology, 37, 912-917. https://doi.org/10.1139/o59-099

Cao, H. L., \& Yu, Z. Y. (1998). Comparative study on the community structure of four different forests in Xiaoliang Experimental Station, Dianbai County, South Guangdong. Chinese Journal of Applied and Environmental Biology, 4, 315-319.

Coleman, D. C. (2008). From peds to paradoxes: Linkages between soil biota and their influences on ecological processes. Soil Biology and Biochemistry, 40, 271-289. https://doi.org/10.1016/j.soilb io.2007.08.005

Crowther, T. W., Maynard, D. S., Leff, J. W., Oldfield, E. E., Mcculley, R. L., Fierer, N., \& Bradford, M. A. (2014). Predicting the responsiveness of soil biodiversity to deforestation: A cross-biome study. Global Change Biology, 20, 2983-2994. https://doi.org/10.1111/gcb.12565

Dassen, S., Cortois, R., Martens, H., de Hollander, M., Kowalchuk, G. A., van der Putten, W. H., \& de Deyn, G. B. (2017). Differential responses of soil bacteria, fungi, archaea and protists to plant species richness and plant functional group identity. Molecular Ecology, 26, 4085-4098. https://doi.org/10.1111/mec.14175

Dawud, S. M., Raulund-Rasmussen, K., Ratcliffe, S., Domisch, T., Finér, L., Joly, F. X., Hättenschwiler, S., \& Vesterdal, L. (2017). Tree species functional group is a more important driver of soil properties than tree species diversity across major European forest types. Functional Ecology, 31, 1153-1162. https://doi.org/10.1111/1365-2435.12821

De Deyn, G. B., Cornelissen, J. H. C., \& Bardgett, R. D. (2008). Plant functional traits and soil carbon sequestration in contrasting biomes. Ecology Letters, 11, 516-531. https://doi. $\operatorname{org} / 10.1111 / \mathrm{j} .1461-0248.2008 .01164 . x$

de Vries, F. T., Liiri, M. E., Bjørnlund, L., Bowker, M. A., Christensen, S., Setälä, H. M., \& Bardgett, R. D. (2012). Land use alters the resistance and resilience of soil food webs to drought. Nature Climate Change, 2, 276-280. https://doi.org/10.1038/nclimate1368

Delgado-Baquerizo, M., Oliverio, A. M., Brewer, T. E., BenaventGonzález, A., Eldridge, D. J., Bardgett, R. D., Maestre, F. T., Singh, B. K., \& Fierer, N. (2018). A global atlas of the dominant bacteria found in soil. Science, 359, 320-325. https://doi.org/10.1126/scien ce.aap9516

Di Sacco, A., Hardwick, K. A., Blakesley, D., Brancalion, P. H. S., Breman, E., Cecilio Rebola, L., Chomba, S., Dixon, K., Elliott, S., Ruyonga, G., Shaw, K., Smith, P., Smith, R. J., \& Antonelli, A. (2021). Ten golden rules for reforestation to optimize carbon sequestration, biodiversity recovery and livelihood benefits. Global Change Biology, 27, 1328-1348. https://doi.org/10.1111/gcb.15498

Dickie, I. A., Xu, B., \& Koide, R. T. (2002). Vertical niche differentiation of ectomycorrhizal hyphae in soil as shown by $T$ RFLP analysis. New Phytologist, 156, 527-535. https://doi. org/10.1046/j.1469-8137.2002.00535.x
Durán, S. M., Sánchez-Azofeifa, G. A., Rios, R. S., \& Gianoli, E. (2015). The relative importance of climate, stand variables and liana abundance for carbon storage in tropical forests. Global Ecology and Biogeography, 24, 939-949. https://doi.org/10.1111/geb.12304

Eisenhauer, N., Beßler, H., Engels, C., Gleixner, G., Habekost, M., Milcu, A., Partsch, S., Sabais, A. C. W., Scherber, C., Steinbeiss, S., Weigelt, A., Weisser, W. W., \& Scheu, S. (2010). Plant diversity effects on soil microorganisms support the singular hypothesis. Ecology, 91, 485496. https://doi.org/10.1890/08-2338.1

Eissfeller, V., Beyer, F., Valtanen, K., Hertel, D., Maraun, M., Polle, A., \& Scheu, S. (2013). Incorporation of plant carbon and microbial nitrogen into the rhizosphere food web of beech and ash. Soil Biology and Biochemistry, 62, 76-81. https://doi.org/10.1016/j.soilb io.2013.03.002

Ekelund, F., Saj, S., Vestergård, M., Bertaux, J., \& Mikola, J. (2009). The "soil microbial loop" is not always needed to explain protozoan stimulation of plants. Soil Biology and Biochemistry, 41, 2336-2342. https://doi.org/10.1016/j.soilbio.2009.08.019

Esquivel-Muelbert, A., Baker, T. R., Dexter, K. G., Lewis, S. L., Brienen, R. J. W., Feldpausch, T. R., Lloyd, J., Monteagudo-Mendoza, A., Arroyo, L., Álvarez-Dávila, E., Higuchi, N., Marimon, B. S., MarimonJunior, B. H., Silveira, M., Vilanova, E., Gloor, E., Malhi, Y., Chave, J., Barlow, J., ... Phillips, O. L. (2019). Compositional response of Amazon forests to climate change. Global Change Biology, 25, 3956. https://doi.org/10.1111/gcb.14413

Farska, J., Prejzkova, K., \& Rusek, J. (2014). Management intensity affects traits of soil microarthropod community in montane spruce forest. Applied Soil Ecology, 75, 71-79. https://doi.org/10.1016/j. apsoil.2013.11.003

Feng, G., Zhang, F. S., Li, X. L., Tian, C. Y., Tang, C., \& Rengel, Z. (2002). Improved tolerance of maize plants to salt stress by arbuscular mycorrhiza is related to higher accumulation of soluble sugars in roots. Mycorrhiza, 12, 185-190. https://doi.org/10.1007/s0057 2-002-0170-0

Ferris, H., \& Bongers, T. (2006). Nematode indicators of organic enrichment. Journal of Nematology, 38, 3-12.

Ferris, H., Bongers, T., \& Goede, R. (2004). Nematode faunal analyses to assess food web enrichment and connectance. In R. C. Cook \& D. J. Hunt (Eds.), Proceedings of the Fourth International Congress of Nematology. Nematology Monographs and Perspectives 2 (pp. 503510). Brill Academic Publishers.

Fierer, N., Strickland, M. S., Liptzin, D., Bradford, M. A., \& Cleveland, C. C. (2009). Global patterns in belowground communities. Ecology Letters, 12, 1238-1249. https://doi. org/10.1111/j.1461-0248.2009.01360.x

Geisen, S., Basten Snoek, L., ten Hooven, F. G., Duyts, H., Kostenko, O., Bloem, J., Martens, H., Quist, C. W., Helder, J. A., \& van der Putten, W. H. (2018). Integrating quantitative morphological and qualitative molecular methods to analyze soil nematode community responses to plant range expansion. Methods in Ecology and Evolution, 9, 1366-1378. https://doi.org/10.1111/2041-210X.12999

Geisen, S., \& Bonkowski, M. (2018). Methodological advances to study the diversity of soil protists and their functioning in soil food webs. Applied Soil Ecology, 123, 328-333. https://doi.org/10.1016/j. apsoil.2017.05.021

Geisen, S., Koller, R., Hünninghaus, M., Dumack, K., Urich, T., \& Bonkowski, M. (2016). The soil food web revisited: Diverse and widespread mycophagous soil protists. Soil Biology and Biochemistry, 94, 10-18. https://doi.org/10.1016/j.soilbio.2015.11.010

George, P. B. L., Lallias, D., Creer, S., Seaton, F. M., Kenny, J. G., Eccles, R. M., Griffiths, R. I., Lebron, I., Emmett, B. A., Robinson, D. A., \& Jones, D. L. (2019). Divergent national-scale trends of microbial and animal biodiversity revealed across diverse temperate soil ecosystems. Nature Communications, 10, 1107. https://doi.org/10.1038/ s41467-019-09031-1 
Govindarajulu, M., Pfeffer, P. E., Jin, H., Abubaker, J., Douds, D. D., Allen, J. W., Bücking, H., Lammers, P. J., \& Shachar-Hill, Y. (2005). Nitrogen transfer in the arbuscular mycorrhizal symbiosis. Nature, 435, 819823. https://doi.org/10.1038/nature03610

Gren, I. M., \& Amuakwa-Mensah, F. (2020). Multifunctional forestry and interaction with site quality. Forests, 11, 29. https://doi. org/10.3390/f11010029

Guerra, C. A., Bardgett, R. D., Caon, L., Crowther, T. W., DelgadoBaquerizo, M., Montanarella, L., Navarro, L. M., Orgiazzi, A., Singh, B. K., Tedersoo, L., Vargas-Rojas, R., Briones, M. J. I., Buscot, F., Cameron, E. K., Cesarz, S., Chatzinotas, A., Cowan, D. A., Djukic, I., van den Hoogen, J., ... Eisenhauer, N. (2021). Tracking, targeting, and conserving soil biodiversity. Science, 371, 239-241. https://doi. org/10.1126/science.abd7926

Gunina, A., Smith, A. R., Godbold, D. L., Jones, D. L., \& Kuzyakov, Y. (2017). Response of soil microbial community to afforestation with pure and mixed species. Plant and Soil, 412, 357-368. https://doi. org/10.1007/s11104-016-3073-0

Handa, I. T., Aerts, R., Berendse, F., Berg, M. P., Bruder, A., Butenschoen, O., Chauvet, E., Gessner, M. O., Jabiol, J., Makkonen, M., Mckie, B. G., Malmqvist, B., Peeters, E. T. H. M., Scheu, S., Schmid, B., van Ruijven, J., Vos, V. C. A., \& Hättenschwiler, S. (2014). Consequences of biodiversity loss for litter decomposition across biomes. Nature, 509, 218-221. https://doi.org/10.1038/ nature13247

Hannula, S., Morriën, E., de Hollander, M., van der Putten, W. H., van Veen, J. A., \& de Boer, W. (2017). Shifts in rhizosphere fungal community during secondary succession following abandonment from agriculture. The ISME Journal, 11, 2294-2304. https://doi. org/10.1038/ismej.2017.90

Harris, J. (2009). Soil microbial communities and restoration ecology: Facilitators or followers? Science, 325, 573-574. https://doi. org/10.1126/science.1172975

Heemsbergen, D. A., Berg, M. P., Loreau, M., van Hai, J. R., Faber, J. H., $\&$ Verhoef, H. A. (2004). Biodiversity effects on soil processes explained by interspecific functional dissimilarity. Science, 306, 10191020. https://doi.org/10.1126/science. 1101865

Hou, E. Q., Chen, C. G., Wen, D. Z., \& Liu, X. (2014). Relationships of phosphorus fractions to organic carbon content in surface soils in mature subtropical forests, Dinghushan, China. Soil Research, 52, 55-63. https://doi.org/10.1071/SR13204

Hu, C., \& Qi, Y. (2010). Effect of compost and chemical fertilizer on soil nematode community in a Chinese maize field. European Journal of Soil Biology, 46, 230-236. https://doi.org/10.1016/j. ejsobi.2010.04.002

IPCC. (2007). Climate change 2007: The physical science basis. In: Contribution of working group I to the fourth assessment report of the intergovernmental panel on climate change. Cambridge University Press.

Kardol, P., Bezemer, T. M., \& van der Putten, W. H. (2006). Temporal variation in plant-soil feedback controls succession. Ecology Letters, 9, 1080-1088. https://doi.org/10.1111/j.1461-0248.2006.00953.x

Kardol, P., \& Wardle, D. A. (2010). How understanding abovegroundbelowground linkages can assist restoration ecology. Trends in Ecology \& Evolution, 25, 670-679. https://doi.org/10.1016/j. tree.2010.09.001

Lagnière, J., Angers, D. A., \& Paré, D. (2010). Carbon accumulation in agricultural soils after afforestation: A metaanalysis. Global Change Biology, 16, 439-453. https://doi. org/10.1111/j.1365-2486.2009.01930.x

Laliberté, E., Kardol, P., Didham, R. K., Teste, F. P., Turner, B. L., \& Wardle, D. A. (2017). Soil fertility shapes belowground food webs across a regional climate gradient. Ecology Letters, 20, 1273-1284. https:// doi.org/10.1111/ele.12823

Lang, C., \& Polle, A. (2011). Ectomycorrhizal fungal diversity, tree diversity and root nutrient relations in a mixed Central European forest.
Tree Physiology, 31, 531-538. https://doi.org/10.1093/treephys/ tpr042

Lefcheck, J. S., Byrnes, J. E. K., Isbell, F., Gamfeldt, L., Griffin, J. N., Eisenhauer, N., Hensel, M. J. S., Hector, A., Cardinale, B. J., \& Duffy, J. E. (2015). Biodiversity enhances ecosystem multifunctionality across trophic levels and habitats. Nature Communications, 6, 6936. https://doi.org/10.1038/ncomms7936

Leff, J. W., Bardgett, R. D., Wilkinson, A., Jackson, B. G., Pritchard, W. J., de Long, J. R., Oakley, S., Mason, K. E., Ostle, N. J., Johnson, D., Baggs, E. M., \& Fierer, N. (2018). Predicting the structure of soil communities from plant community taxonomy, phylogeny, and traits. The ISME Journal, 12, 1749-1805. https://doi.org/10.1038/ s41396-018-0089-x

Li, Z., Weng, H., \& Yu, Z. (1996). Effects of man-made forest on eroded soils in tropical region in Guangdong. Tropical Geography, 16, 311-318.

Liu, J. L., Dang, P., Gao, Y., Zhu, H. L., Zhu, H. N., Zhao, F., \& Zhao, Z. (2018). Effects of tree species and soil properties on the composition and diversity of the soil bacterial community following afforestation. Forest Ecology and Management, 427, 342-349. https://doi. org/10.1016/j.foreco.2018.06.017

Liu, M. Y., Xia, H. P., Fu, S. L., \& Eisenhauer, N. (2017). Tree diversity regulates soil respiration through accelerated tree growth in a mesocosm experiment. Pedobiologia, 65, 24-28. https://doi. org/10.1016/j.pedobi.2017.05.005

Liu, T., Chen, X. Y., Gong, X., Lubbers, I. M., Jiang, Y. Y., Feng, W., Li, X. P., Whalen, J. K., Bonkowski, M., Griffiths, B. S., Hu, F., \& Liu, M. Q. (2019). Earthworms coordinate soil biota to improve multiple ecosystem functions. Current Biology, 29, 3420-3429. https://doi. org/10.1016/j.cub.2019.08.045

Lowman, M., Devy, S., \& Ganesh, T. (2013). Treetops at risk: Challenges of global canopy ecology and conservation. Springer.

Lu, C. H. (2000). Analytical methods for soils and agricultural chemistry. Scientific and Technology Press.

Makarieva, A. M., \& Gorshkov, V. G. (2007). Biotic pump of atmospheric moisture as driver of the hydrological cycle on land. Hydrology and Earth System Sciences, 11, 1013-1033. https://doi.org/10.5194/ hess-11-1013-2007

Malhi, Y. (2012). The productivity, metabolism and carbon cycle of tropical forest vegetation. Journal of Ecology, 100, 65-75. https://doi. org/10.1111/j.1365-2745.2011.01916.x

Montagnini, F., \& Jordan, C. F. (2005). Tropical forests ecology: The basis for conservation and management. Springer.

Moomaw, W. R., Law, B. E., \& Goetz, S. J. (2020). Focus on the role of forests and soils in meeting climate change mitigation goals: Summary. Environmental Research Letters, 15, 045009. https://doi. org/10.1088/1748-9326/ab6b38

Morriën, E., Hannula, S. E., Snoek, L. B., Helmsing, N. R., Zweers, H., de Hollander, M., Soto, R. L., Bouffaud, M., Buée, M., Dimmers, W., Duyts, H., Geisen, S., Girlanda, M., Griffiths, R. I., Jørgensen, H., Jensen, J., Plassart, P., Redecker, D., Schmelz, R. M., ... van der Putten, W. H. (2017). Soil networks become more connected and take up more carbon as nature restoration progresses. Nature Communications, 8, 14349. https://doi.org/10.1038/ncomms14349

Myers, N. (1979). The sinking ark: A new look at the problem of disappearing species. Pergamon Press.

Nielsen, U. N., Ayres, E., Wall, D. H., \& Bardgett, R. D. (2011). Soil biodiversity and carbon cycling: A review and synthesis of studies examining diversity-function relationships. European Journal of Soil Science, 62, 105-116. https://doi.org/10.1111/j.1365-2389.2010.01314.x

Orwin, K. H., Wardle, D. A., \& Greenfield, L. G. (2006). Ecological consequences of carbon substrate diversity and identity. Ecology, 87, 580-593. https://doi.org/10.1890/05-0383

Pawson, S. M., Brin, A., Brockerhoff, E. G., Lamb, D., Payn, T. W., Paquette, A., \& Parrotta, J. A. (2013). Plantation forests, climate change and 
biodiversity. Biodiversity and Conservation, 22, 1203-1227. https:// doi.org/10.1007/s10531-013-0458-8

Paz-Ferreiro, J., Gascó, G., Gutiérrez, B., \& Méndez, A. (2012). Soil biochemical activities and the geometric mean of enzyme activities after application of sewage sludge and sewage sludge biochar to soil. Biology and Fertility of Soils, 48, 511-517. https://doi. org/10.1007/s00374-011-0644-3

Poorter, L., Bongers, F., Aide, T. M., Almeyda Zambrano, A. M., Balvanera, P., Becknell, J. M., Boukili, V., Brancalion, P. H. S., Broadbent, E. N., Chazdon, R. L., Craven, D., de Almeida-Cortez, J. S., Cabral, G. A. L., de Jong, B. H. J., Denslow, J. S., Dent, D. H., DeWalt, S. J., Dupuy, J. M., Durán, S. M., ... Rozendaal, D. M. A. (2016). Biomass resilience of Neotropical secondary forests. Nature, 530, 211-214. https:// doi.org/10.1038/nature16512

Porazinska, D. L., Giblin-Davis, R. M., Faller, L., Farmerie, W., Kanzaki, N., Morris, K., Powers, T. O., Tucker, A. E., Sung, W., \& Thomas, W. K. (2009). Evaluating high-throughput sequencing as a method for metagenomic analysis of nematode diversity. Molecular Ecology Resources, 9, 1439-1450. https://doi.org/10.1111/j.1755-0998.2009.02611.x

Preece, C., \& Peñuelas, J. (2016). Rhizodeposition under drought and consequences for soil communities and ecosystem resilience. Plant and Soil, 409, 1-17. https://doi.org/10.1007/s11104-016-3090-z

Pugh, T. A. M., Lindeskog, M., Smith, B., Poulter, B., Arneth, A., Haverd, V., \& Calle, L. (2019). Role of forest regrowth in global carbon sink dynamics. Proceedings of the National Academy of Sciences of the United States of America, 116, 4382-4387. https://doi.org/10.1073/ pnas.1810512116

R Development Core Team. (2016). R: A language and environment for statistical computing. R Foundation for Statistical Computing.

Ren, C. J., Zhao, F. Z., Kang, D., Yang, G. H., Han, X. H., Tong, X. G., Feng, Y. Z., \& Ren, G. X. (2016). Linkages of C: N: P stoichiometry and bacterial community in soil following afforestation of former farmland. Forest Ecology and Management, 376, 59-66. https://doi. org/10.1016/j.foreco.2016.06.004

Ren, H., Li, Z. A., Shen, W. J., Yu, Z. Y., Peng, S. L., Liao, C. H., Ding, M. M., $\&$ Wu, J. G. (2007). Changes in biodiversity and ecosystem function during the restoration of a tropical forest in south China. Science in China Series C: Life Sciences, 50, 277-284. https://doi.org/10.1007/ s11427-007-0028-y

Rillig, M. C., Wright, S. F., \& Eviner, V. T. (2002). The role of arbuscular mycorrhizal fungi and glomalin in soil aggregation: Comparing effects of five plant species. Plant and Soil, 238, 325-333. https://doi. org/10.1023/A:1014483303813

Rousk, J., Bååth, E., Brookes, P. C., Lauber, C. L., Lozupone, C., Caporaso, J. G., Knight, R., \& Fierer, N. (2010). Soil bacterial and fungal communities across a pH gradient in an arable soil. The ISME Journal, 4 1340-1351. https://doi.org/10.1038/ismej.2010.58

Saleem, M., Hu, J., \& Jousset, A. (2019). More than the sum of its parts: Microbiome biodiversity as a driver of plant growth and soil health. Annual Review of Ecology, Evolution and Systematics, 50, 145-168. https://doi.org/10.1146/annurev-ecolsys-110617-062605

Sánchez-Moreno, S., \& Ferris, H. (2007). Suppressive service of the soil food web: Effects of environmental management. Agriculture, Ecosystems and Environment, 119, 75-87. https://doi.org/10.1016/j. agee.2006.06.012

Scherber, C., Eisenhauer, N., Weisser, W. W., Schmid, B., Voigt, W., Fischer, M., Schulze, E., Roscher, C., Weigelt, A., Allan, E., Beßler, H., Bonkowski, M., Buchmann, N., Buscot, F., Clement, L. W., Ebeling, A., Engels, C., Halle, S., Kertscher, I., ... Tscharntke, T. (2010). Bottom-up effects of plant diversity on multitrophic interactions in a biodiversity experiment. Nature, 468, 553-556. https://doi. org/10.1038/nature09492

Schloss, P. D., Westcott, S. L., Ryabin, T., Hall, J. R., Hartmann, M., Hollister, E. B., Lesniewski, R. A., Oakley, B. B., Parks, D. H., Robinson, C. J., Sahl, J. W., Stres, B., Thallinger, G. G., Van Horn, D. J., \& Weber, C. F. (2009). Introducing Mothur: Open-source, platform-independent, community-supported software for describing and comparing microbial communities. Applied and Environmental Microbiology, 75, 7537-7541. https://doi.org/10.1128/AEM.01541-09

Schneider, T., Keiblinger, K. M., Schmid, E., Sterflinger-Gleixner, K., Ellersdorfer, G., Roschitzki, B., Richter, A., Eberl, L., ZechmeisterBoltenstem, S., \& Riedel, K. (2012). Who is who in litter decomposition? Metaproteomics reveals major microbial players and their biogeochemical functions. The ISME Journal, 6, 1749-1762. https:// doi.org/10.1038/ismej.2012.11

Soliveres, S., van der Plas, F., Manning, P., Prati, D., Gossner, M. M., Renner, S. C., Alt, F., Arndt, H., Baumgartner, V., Binkenstein, J., Birkhofer, K., Blaser, S., Blüthgen, N., Boch, S., Böhm, S., Börschig, C., Buscot, F., Diekötter, T., Heinze, J., ... Allan, E. (2016). Biodiversity at multiple trophic levels is needed for ecosystem multifunctionality. Nature, 536, 456-459. https://doi.org/10.1038/nature19092

Srivastava, D. S., Cardinale, B. J., Downing, A. L., Duffy, J. E., Jouseau, C., Sankaran, M., \& Wright, J. P. (2009). Diversity has stronger topdown than bottom-up effects on decomposition. Ecology, 90, 10731083. https://doi.org/10.1890/08-0439.1

Stephens, B. B., Gurney, K. R., Tans, P. P., Sweeney, C., Peters, W., Bruhwiler, L., Ciais, P., Ramonet, M., Bousquet, P., Nakazawa, T., Aoki, S., Machida, T., Inoue, G., Vinnichenko, N., Lloyd, J., Jordan, A., Heimann, M., Shibistova, O., Langenfelds, R. L., ... Denning, A. S. (2007). Weak northern and strong tropical land carbon uptake from vertical profiles of atmospheric $\mathrm{CO}_{2}$. Science, 316, 1732-1735. https://doi.org/10.1126/science.1137004

Stott, D. E. (2019). Recommended soil health indicators and associated laboratory procedures. Soil Health Technical Note No. 450-03. U.S. Department of Agriculture, Natural Resources Conservation Service.

Strukelj, M., Parker, W., Corcket, E., Augusto, L., Khlifa, R., Jactel, H., $\&$ Munson, A. D. (2021). Tree species richness and water availability interact to affect soil microbial processes. Soil Biology and Biochemistry, 155, 108180. https://doi.org/10.1016/j.soilb io. 2021.108180

Szoboszlay, M., Dohrmann, A. B., Poeplau, C., Don, A., \& Tebbe, C. C. (2017). Impact of land-use change and soil organic carbon quality on microbial diversity in soils across Europe. FEMS Microbiology Ecology, 93, fix146. https://doi.org/10.1093/femsec/fix146

Taubert, F., Fischer, R., Groeneveld, J., Lehmann, S., Müller, M. S., Rödig, E., Wiegand, T., \& Huth, A. (2018). Global patterns of tropical forest fragmentation. Nature, 554, 519-522. https://doi.org/10.1038/ nature25508

van der Werf, G. R., Morton, D. C., DeFries, R. S., Olivier, J. G. J., Kasibhatla, P. S., Jackson, R. B., Collatz, G. J., \& Randerson, J. T. (2009). $\mathrm{CO}_{2}$ emissions from forest loss. Nature Geoscience, 2, 737738. https://doi.org/10.1038/ngeo671

Veldkamp, E., Schmidt, M., Powers, J. S., \& Corre, M. D. (2020). Deforestation and reforestation impacts on soils in the tropics. Nature Reviews Earth and Environment, 1, 590-605. https://doi. org/10.1038/s43017-020-0091-5

Wagg, C., Bender, S. F., Widmer, F., \& van der Heijden, M. G. A. (2014). Soil biodiversity and soil community composition determine ecosystem multifunctionality. Proceedings of the National Academy of Sciences of the United States of America, 111, 5266-5270. https:// doi.org/10.1073/pnas.1320054111

Wang, F. M., Ding, Y. Z., Sayer, E. J., Li, Q. L., Zou, B., Mo, Q. F., Li, Y. W., Lu, X. L., Tang, J. W., Zhu, W. X., \& Li, Z. A. (2017). Tropical forest restoration: Fast resilience of plant biomass contrasts with slow recovery of stable soil C stocks. Functional Ecology, 31, 2344-2355. https://doi.org/10.1111/1365-2435.12925

Wang, F. M., Li, J., Zou, B., Xu, X., \& Li, Z. A. (2013). Effect of prescribed fire on soil properties and $\mathrm{N}$ transformation in two-vegetation types in South China. Environmental Management, 51, 1164-1173. https://doi. org/10.1007/s00267-013-0044-6

Wang, K. B., Zhang, Y. W., Tang, Z. S., Shangguan, Z. P., Chang, F., Jia, F. A., Chen, Y. P., He, X. H., Shi, W. Y., \& Deng, L. (2019). Effects of 
grassland afforestation on structure and function of soil bacterial and fungal communities. Science of the Total Environment, 676, 396406. https://doi.org/10.1016/j.scitotenv.2019.04.259

Wen, D., Wei, P., Zhang, Q., \& Kong, G. (1999). Studies on biomass of three lower subtropical evergreen broad-leaved forest in a MAB reserve of South China. Acta Phytoecologica Sinica, 23, 11-21.

Whitehead, A. G., \& Hemming, J. R. (1965). A comparison of some quantitative methods of extracting small vermiform nematodes from soil. Annals of Applied Biology, 55, 25-38. https://doi.org/10.1111/ j.1744-7348.1965.tb07864.x

Wilson, G. W. T., Rice, C. W., Rillig, M. C., Springer, A., \& Hartnett, D. C. (2009). Soil aggregation and carbon sequestration are tightly correlated with the abundance of arbuscular mycorrhizal fungi: Results from long-term field experiments. Ecology Letters, 12, 452-461. https://doi.org/10.1111/j.1461-0248.2009.01303.x

Xiong, W., Jousset, A., Guo, S., Karlsson, I., Zhao, Q. Y., Wu, H. S., Kowalchuk, G. A., Shen, Q. R., Li, R., \& Geisen, S. (2018). Soil protist communities from a dynamic hub in the soil microbiome. The ISME Journal, 12, 634-638. https://doi.org/10.1038/ismej.2017.171

Yao, Q., Zheng, L., \& Peng, S. (1984). The erosion of weathering crust in granite tableland and its remediation at Xiaoliang. Tropical and Subtropical Forest Ecosystem, 2, 91-106.

Yeates, G. W. (2003). Nematodes as soil indicators: Functional and biodiversity aspects. Biology and Fertility of Soils, 37, 199-210. https:// doi.org/10.1007/s00374-003-0586-5

Yeates, G. W., Bongers, T., de Goede, R. G. M., Freckman, D. W., \& Georgieva, S. S. (1993). Feeding habits in soil nematode families and genera-An outline for soil ecologists. Journal of Nematology, 25, 315-331.

Yu, Z., \& Pi, Y. (1985). The path and its effects of rehabilitating vegetation on the tropical littoral eroded land in Guangdong province. Tropical and Subtropical Forest Ecosystem Research, 3, 97-108.

Zhang, S. X., Chang, L., McLaughlin, N. B., Cui, S. Y., Wu, H. T., Wu, D. H., Liang, W. J., \& Liang, A. Z. (2021). Complex soil food web enhances the association between $\mathrm{N}$ mineralization and soybean yield-A model study from long-term application of a conservation tillage system in a black soil of Northeast China. Soil, 7, 71-82. https://doi. org/10.5194/soil-7-71-2021

Zhou, Z. H., Wang, C. K., \& Jin, Y. (2017). Stoichiometric responses of soil microflora to nutrient additions for two temperate forest soils. Biology and Fertility of Soils, 53, 397-406. https://doi.org/10.1007/ s00374-017-1188-y

Zhou, Z. H., Wang, C. K., \& Luo, Y. Q. (2018). Effects of forest degradation on microbial communities and soil carbon cycling: A global metaanalysis. Global Ecology and Biogeography, 27, 110-124. https://doi. org/10.1111/geb.12663

Zhu, Y., Wang, Y. F., \& Chen, L. D. (2019). Responses of ground-active arthropods to black locust (Robinia pseudoacacia L.) afforestation in the Loess Plateau of China. Catena, 183, 104223. https://doi. org/10.1016/j.catena.2019.104233

\section{SUPPORTING INFORMATION}

Additional supporting information may be found online in the Supporting Information section.

How to cite this article: Wu, W., Kuang, L., Li, Y., He, L., Mou, Z., Wang, F., Zhang, J., Wang, J., Li, Z., Lambers, H., Sardans, J., Peñuelas, J., Geisen, S., \& Liu, Z. (2021). Faster recovery of soil biodiversity in native species mixture than in Eucalyptus monoculture after 60 years afforestation in tropical degraded coastal terraces. Global Change Biology, 00, 1-12. https://doi.org/10.1111/gcb.15774 